editorial note, "Mankind and Outer Space", and an article by Prof. R. Courant, "General Problems confronting Computing Centres", both stress the opportunities and the importance of international cooperation in these fields. Dr. G. H. O. Burgess, of the Torry Research Station, reviews the contribution which fish technology can make to the food supply of the world and stresses the need for a much greater research effort and more attention to the dissemination of the results of research. Dr. G. Charlesworth, now head of the London Traffic Management Unit, Ministry of Transport, writing on "Science and the Road Traffic Problem", describes some of the contributions which research has made in this field, and the opportunities which the scientific study of roads and traffic presents both in the prevention of accidents and improving the efficiency of transport.

\section{Education and Training in France}

IN May 1960 nine members of the West Regional Group of the British Association for Commercial and Industrial Education paid a visit to France to study the French system of education and training with special reference to the needs of industry. Their report contains a comprehensive description of the present system of education and training in France, as well as the changes in the system which will take place during the next few years as a result of legislation enacted in 1959 (Pp. v +5l. London: British Association for Commercial and Industrial Education, 1961. 10s.). When reforms are completely integrated, all children will remain at school until sixteen years of age and selection for vocational training will commence well before the end of the normal sehool eareer. A large section of the report is devoted to the various types of vocational institutions which exist, the certificates and diplomas awarded and educational practice in the vocational sehools. There is also a detailed description of education and training at the three main factories of the Renault Works.

\section{Television and School Teaching}

IN a booklet on schools television, the National Union of Teachers suggests that television should not be considered as a substitute for the teacher but as an addition to teaching aids already available (Schools Television: a Discussion Document. Pp. 18. London: National Union of Teachers, 1961. 1s.); that if television is to be regarded as an integral part of the apparatus of education, it should be the responsibility of local education authorities to provide sets; and that particular attention should be directed to the need for the provision of more television sets in primary schools. The booklet quotes some of the findings from the Union's inquiry on schools television among 111 schools, distributed over the areas of 71 locel education authorities, and compares them with similar findings in the B.B.C. report. The National Union of Teachers welcomes the setting up by the B.B.C. and commercial companies of special bod'es with responsibility for the form and content of the schools programmes, and comments favourably on the "degree of independence of the parent body" wh:ch the Schools Broadcasting Department of the B.B.C. and its counterparts in commercial television enjoy. The booklet examines the constitution of these bodies, the scope of their work, the special role of the Union therein, and their relationships with the schools. The pamphlet states that "the principal limitations of the television programme compared with the film . . . are that it is not under the control of the teacher to the same extent either before, during or after showing, and that it has not the same resources of colour presentation". On the other hand, it points out that "television has a great impact on account of its immediacy". The booklet also touches on the general impact of television viewing on children and the special position of Wales with regard to television.

\section{The British Broadcasting Corporation}

Is the annual report and accounts of the British Broadcasting Corporation for $1960-61$ it is recommended that the higher-frequency bands, Bands IV and $\mathrm{V}$, should be used for television with a change of line standard from 405 to 625 lines, as proposed by the Postmaster-General's Television Advisory Committee, and that two of the four channels available in the higher-frequency bands should be allotted to the B.B.C. One channel would be used for an entirely new programme service so that the B.B.C. could give viewers a genuine choice of balanced alternative programmes, while a second channel would carry the existing Band I service, duplicated on the 625-line standard. The B.B.C. recommends that the channels in Band III, not at present allocated to either B.B.C. or the Independent Television Authority, should be used to improve the coverage of existing services in areas not well served at present, and, in particular. to provide an improved and distinctive service for Wales. The B.B.C. is carrying on with its experimental work on colour television with the approval of the Post Office and with support from the radio industry. The experiments will include test transmissions in colour on 625 lines in Bands IV and V, thus extending the work already done by the B.B.C. in the experimental transmissions on 625 lines in black and white. On sound broadcasting, the report states that there is need for an earlier start to the day's programmes . . . a similar extension is needed at the other end of the day, after midnight, for latenight workers. Over and above the provision of three programme services, the B.B.C. sees the need and the opportunity now for a supplementary fourth service in the form of local sound broadcasting on very high frequencies.

\section{Licentiateships in Printing and Furniture}

For some time both the printing and furniture industries, in association with the City and Guilds of London Institute, have been developing advanced courses at a level beyond the full technological certificate to meet specific requirements for highlevel qualifications for which, at present, there are no recognized awards. The Institute has announced recently a new award, the licentiateship of the City and Guilds of London Institute, intended to provide that kind of recognition in selected fields where such a need exists. The Institute has approved two such fields, printing and furniture, and the awards will be known as the Licentiateship in Printing of the City and Guilds of London Institute and the Licentiateship in Furniture of the City and Guilds of London Institute. Candidates for either award must have had at least five years approved industrial experience after completion of apprenticeship. In printing, a candidate will be required to have obtained one of the Institute's eraft certificates, have obtained the full technological certificate and have passed the examination for advanced qualifications. In furniture, a candidate must have obtained a craft course 